\title{
The Public Broadcaster in Love with Commercials
}

\author{
By Gerald Pratley
}

Fall 1998 Issue of KINEMA

Seldom does a day pass by without Canadian Broadcasting Corporation TV being mentioned, for one reason or the other, in the media or in political circles, either with unfavourable comments or occasionally, compliments. Great storms of fury arise over its administration, its policies and appointments, its programming and financial distress. It is harangued, it is laughed at, it is loyally defended by Ian Morrison and his Friends of Canadian Broadcasting. The government is blamed for decisions it has taken, and for measures it hasn't carried out, to benefit the CBC.

But in these ceaseless debates, nothing is ever said, within the CBC or outside seemingly, among its viewers, about the greatest blight ever to settle over the CBC and this is the curse of commercials. Does this mean that to the CBC's entire staff and to its faithful "the CBC no matter what" supporters, this contentious subject is no longer an issue when we discuss the responsibilities of our public broadcaster? Even more disturbing is the realisation that an entire generation is growing up believing that it is perfectly natural for television programmes to be constantly interrupted by mostly inane advertising, and they would be missed if they were to be omitted.

For privately owned television stations and networks it is accepted that for them to exist (but one wonders most of the time why they should) they must sell their time to advertising agencies even though we are told the airwaves are publicly not privately owned. It follows then that sitcoms, documentaries and similar programmes are written and devised to fall into acts between which commercials will be inserted. At this time many viewers press 'mute' on their control and read the paper while the hucksters go to work, usually loud and abominably. When these stations show movies however, and other programmes not devised to take commercials at certain times, their narratives are wrenched apart to make room for them. Those who care enough record the programs or films they like on their VCR's and fast-forward through the intrusions during playback.

The CBC however is publicly owned and paid for by all Canadians with their income tax, the GST and other taxes. The CBC brags about being a public broadcaster, but it is not in the true sense of the word and is scorned by public broadcasters abroad by claiming to be such while interrupting its programmes with mostly false statements from advertisers. And the Americans, free enterprisers to the last, cannot understand why a crown corporation paid for by the people should be allowed to take commercials at the expense of private broadcasters. The CBC cannot even show us a movie (Canadian or otherwise) at midnight without irritating commercial breaks. And when it cannot sell advertising time, the CBC still breaks into narratives with programme announcements played over and over again until viewers are so tired of them they feel disinclined to watch them when they are finally shown.

Why does it do this? Because although it is Canadian the CBC really wants to look and sound American. It envies CBS, NBC, ABC; they are loud and supposedly lively, fast and clamorous with their constant commercial announcements and superficial programmes. The CBC thinks the public is only at ease with this style of presentation, one commercial after another -- a 30-minute programme runs 22 minutes, a 60 minute runs 47 minutes, yet another commercial comes before the closing credits and then the credits are squashed into a corner to put in yet another commercial while an off-screen announcer urges viewers to stay "with us" for the broadcast following. Our "public broadcaster" inserts commercials into the National News and floods Newsworld with them, just like the vulgar CTV with its broadcasts. And not only does the CBC interrupt its own News it breaks into the BBC "shrinking" it in a most discourteous manner to make way for CBC headlines -- which have been on during the previous hour and will be on again at 7:00pm. Many viewers think the $\mathrm{BBC}$ is running commercials. (CBC Radio, compared to $\mathrm{CBC}-\mathrm{TV}$, provides a consistently more satisfying service, as does Société Radio-Canada in Québec in spite of its separatist sympathies.)

The unimaginative individuals who run the English-language CBC rush in and claim that the government forced them to take commercials by cutting their funds. This is the immediate and easy response and no one seems interested in looking further into this situation to see what other measures could be taken, mainly 
because no one at the CBC wants to do so. Just leave things as they are. We do not want to look different from the US networks. The public does not want us to! The CBC still gets around $\$ 900$ million annually and where does it all go? How many vice-presidents are still sitting in Ottawa together with the useless Board of Governors? Does the revenue from commercials become so precious that the CBC will sell its soul -- if it has one these days, to the advertisers. Look around and see how the CBC wastes our money on large billboard advertising and the sums it pays out for other services which could easily be dispensed with. And are we really to believe that the CBC's programme decisions are not influenced by advertisers and that many programmes it ought to be creating and supporting are not being made because it is fearful of not getting advertising? And what about that secretive group inside the CBC in charge of the commercial department who thoughtlessly decide where and how many times under CRTC rulings, they can force their mendacious messages into the daily schedules without any thought being given as to the subject matter of the programmes. Sensitivity to content is absent.

Why does nothing change? Because no one in control of the $\mathrm{CBC}$ wants to change. No one there has a conscience which tells them that the $\mathrm{CBC}$ should not be dependent on money from advertisers. We are presently watching a moving series about the part our armed forces played in WWII -- is such an important chronicle of history and humanity free from commercials? Of course not, and the depiction of the suffering of soldiers dying for our freedom is used to permit merchants to present their wares -- from driving fast cars to selling powder for itching feet. Good taste is a quality the CBC has lost.

Over the past year or so the CBC has given us more Canadian programming in the evenings than we have seen for many years, and this is both welcome and appreciated, although one cannot help feeling a sense of disgust at the hypocrisy of CBC programmers in announcing "the Canadianization" of the coming seasons as if they were the heroes of the hour bringing us a brand new mandate. The CBC was set up to be Canadian and should never have been allowed to become "Americanized" as it has been.

Nonetheless, these "new" Canadian programmes will be commercial carriers crowded in at every turn. And now we are sliding back into the old habits. This summer we are being given mostly mediocre American movies, extravagantly promoted on air, that are also to be found on commercial stations. Does the CBC have to compete with them? What huge sums did they pay for them? Don't ask, no one does. The CBC would rather be in Hollywood than at home. It thinks showing these films puts it in the Big League. This love of commercials of course is linked with the CBC's other obsession: ratings. It measures its success not by the quality of what it puts out but by how many people watch whatever it puts out; when it comes to summer programming or all year round programming, the CBC, (like the American dominated CTV, Global and City TV) prefers to ignore excellent British programmes $\mathrm{CBC}$ viewers would like to see. (They are forced to turn to PBS.) Many of them are bought by the specialized channels whose budgets are minuscule compared to the money the $\mathrm{CBC}$ has available, but whose audiences are small because of high cable rates. (We are lucky to get Coronation Street which in the UK carries one commercial in a half-hour broadcast compared with five during a CBC broadcast. Think of the cuts made to accommodate them.) Consider this: where are our classical musicians, singers, opera and ballet stars, those who are established and the beginners, seeking a future audience?

Throwing money at the $\mathrm{CBC}$ will not necessarily eliminate regrettable practices because those in charge really want commercials. It is their thinking and perspective which has to change. Instead of a Perrin Beatty we need a Davidson Dunton or a John Grierson. But there are none like them -- or if there are they are pushed aside. Only television critics escape the plague; they see programmes in advance without commercials. They can praise a programme which, when seen with so many commercial breaks, is not the same thing at all! It is we, the public, who suffer, and it's time we opened a window and shouted "we are not going to take it anymore". But will it do any good if no one in command really cares and the public as a whole cares even less?

There are thousands of loyal CBC supporters who would prefer to see their tax money supporting a CBC which has the courage and integrity of a PBS rather than in making it look and sound like a CBS. 


\section{Author Information}

Gerald PRATLEY, OC, LLD, started his career as film critic with the CBC. In 1969, he founded the Ontario Film Institute which he directed until 1990. He has written several books and numerous articles on film, including Torn Sprockets, a history of Canadian cinema. He taught Film History in universities in Toronto and Waterloo, Canada and holds three honorary degrees from Canadian and US universities.

Gerald A. Pratley (1923-2011) was born and educated in London, England, and came to Canada in 1946. He started working in Toronto for the $\mathrm{CBC}$ as a scriptwriter. He was drawn toward working in motion pictures, and became, in 1948, the CBC's first film critic and commentator.

Gerald Pratley broadcast three programmes a week, Pratley at the Movies, The Movie Scene, Music From the Films, and others, until 1975. During this time he also became the first post-war chairman of the Toronto Film Society, chairman of the Toronto and District Film Council and co-founder of the A-G-E Film Society and correspondent for international magazines such as Films and Filming, Film In Review, Variety, Hollywood Quarterly and International Film Guide. During the 1950s he wrote for Canadian Film Weekly and Canadian Film Digest.

He became known as a speaker on all aspects of motion picture art and industry, and was invited to teach film history at the University of Toronto, York University, University of Waterloo, Seneca College and Ryerson Polytechnical University, with individual lectures being given at many other Canadian and US universities and colleges. He has served as a member of various judging panels of competitions and festivals, being one of the members of the first Canadian Film Awards in 1949.

From 1970 to 1975 he was the director of the Stratford (Ontario) International Film Festival, and from 1969 to 1976 he was Chairman of the International Jury of the Canadian Film Awards. He has attended all the world's leading festivals of film, and in particular, for 30 years, the Cannes Festival as CBC correspondent. He has written six books, The Films of Frankenheimer: Forty Years in Film; The Cinema of John Frankenheimer; The Cinema of Otto Preminger; The Cinema of David Lean; The Cinema of John Huston, and Torn Sprockets, a history of the Canadian cinema.

Gerald Pratley has served on the Advisory Boards of the film departments of Ryerson Polytechnical University and Humber College, and as a member of the programme committee of TV Ontario. In 1968 he became the founder-director of the Ontario Film Institute of the Province of Ontario, an organization which has

distinguished itself in archival holdings and public service and is known since 1990 as the Cinematheque of Ontario. He taught Film History courses at the Department of Film and Photography, Ryerson Polytechnic University, Toronto and the University of Waterloo.

In 1984, Gerald Pratley was made a Member of the Order of Canada and in 2003 Officer of the Order of Canada for his service to Canada through film appreciation. He holds Honorary Degrees in Letters and Fine Arts from York and Waterloo Universities (Ont., Canada) and Bowling Green State University (Ohio, USA).

In 2002, Gerald Pratley received a Special Genie Award from the Academy of Canadian Cinema \& Television in recognition of his lifelong dedication to the promotion and his exceptional support of Canadian cinema.

He died on 14 March 2011 in Ontario, Canada. 